Relations industrielles

Industrial Relations

\title{
A Note of the Critical Dimensions of the Union Merger Process
}

\section{Gary N. Chaison}

Volume 37, numéro 1, 1982

URI : https://id.erudit.org/iderudit/029239ar

DOI : https://doi.org/10.7202/029239ar

Aller au sommaire du numéro

\section{Éditeur(s)}

Département des relations industrielles de l'Université Laval

\section{ISSN}

0034-379X (imprimé)

1703-8138 (numérique)

Découvrir la revue

Citer cet article

Chaison, G. N. (1982). A Note of the Critical Dimensions of the Union Merger Process. Relations industrielles / Industrial Relations, 37(1), 198-206.

https://doi.org/10.7202/029239ar

Tous droits réservés (C) Département des relations industrielles de l'Université Laval, 1982
Ce document est protégé par la loi sur le droit d'auteur. L'utilisation des services d'Érudit (y compris la reproduction) est assujettie à sa politique d'utilisation que vous pouvez consulter en ligne.

https://apropos.erudit.org/fr/usagers/politique-dutilisation/ 


\title{
DISCUSSIONS
}

\section{A Note on the Critical Dimensions of the Union Merger Process}

\author{
Gary N. Chaison
}

In the past decade, there has been a resurgence of interest in the union merger process. Mergers have been examined from historical (Chaison, 1972; Graham, 1970), legal (Coady, 1976) and organizational behaviour perspectives (Freeman and Brittain, 1977). Chronicles of merger activity have been prepared by Dewey (1971) and by Janus (1978) for the United States, while the frequency and reasons for mergers have been reviewed by Chaison (1979), 1980a) for Canada, by Elias (1973), Winsbury (1969) and Buchanan (1974) for Great Britain, and by Khoury (1978) for Australia. Brooks and Gamm (1976) have examined the impact of mergers on collective bargaining and union democracy for selected cases.

Despite the recent interest in mergers, there is no general theoretical model which can be applied to the merger process (Chitayat, 1975, 1979). The theory of corporate mergers is of limited relevancy, primarily because of the different financial motivation in union mergers as well as the requirements for membership approval. Moreover, union and business mergers differ because the former may involve some deep-seated animosities between officers as well as an element of tradition in the desire to carry on a dying organization in the face of the apparent benefits of merger. The recent flurry or research activity points to the need for establishing at least a foundation for a comprehensive and comparative theory of the merger process. This paper will briefly describe the critical dimensions of union mergers that will have to be considered in any research leading to such a theory. These are reviewed under the categories of a) the generalizability of mergers, b) the timing of the merger process, c) the distinction between amalgamations and absorptions, d) the merger as a continuing process, e) the alliance as an alternative to the merger, and f) the unsuccessful merger negotiations.

\section{The Generalizability of Mergers}

As examinations of union mergers move from case studies to aggregate data analyses, questions arise regarding the extent to which generalizations can be safely made. Chitayat $(1975,1979)$ claimed that one of the primary

* CHAISON, Gary N., Professor, School of Management, Clark University, Worcester, Mass.

Relat. ind., vol. 37, no 1 (1982) () PUL ISSN 0034-379 X 
barriers to the development of a comprehensive theory of union mergers is the difficulty of producing any general conclusions about their causes, process and effects. This idiosyncratic nature of mergers was recognized by Coady who claimed that while it is possible to identify factors which exert strong influences on particular mergers, "every merger is a response to the special needs of the unions involved, and can be expressed only tenuously by reference to generalized social conditions".' (Coady, 1976, p. 10.)

The following cases illustrate the complexity of the merger process and the historical, political and structural diversity that would be neglected in analyses of aggregate data:

1. Chaison (1980) described how the presence of international unions causes mergers in Canada are to often be the result of decisions made in the United States. Canadian sections have at times resisted the merger efforts of their international parent unions, while in other instances mergers of Canadian sections of internationals have been blocked at U.S. headquarters. The growing movement for the autonomy of Canadian sections has been shown to have an impact on the rate and form of mergers in both the United States and Canada.

2. In 1976 the Professional Air Traffic Controllers Organization (PATCO) merged with the National Association of Air Traffic Specialists. However, PATCO was also an affiliate of the National Marine Engineers' Benevolent Association. Janus (1978) observed that this merger between a union and another union's affiliate adds a complicating layer to the merger process. In addition, mergers may occur among the semiautonomous affiliates within some unions. For example, the Seafarers' International Union has been amalgamating its internal structure, with the SIU Atlantic and Gulf District absorbing two other affiliates, the Inland Boatmen in 1976 and the Marine Cooks and Stewards in 1979.

3. Some mergers are not the complete combining of one organization into another. In 1979, the Lathers were absorbed by the Carpenters, but by special arrangement their New York City local became part of the Ironworkers, a union with which it shared a similar jurisdiction in that area. Also, there have been mergers of international unions occurring in the United States without corresponding mergers among their Canadian sections (Chaison, 1980).

4. Although most mergers involve two unions, in the period 1900 to 1978 in the United States there were two mergers of three unions each, two of four unions each and one joining five unions (Chaison, 1980b). In Canada, five unions amalgamated in 1976 to form the National Union of Provincial Government Employees and have since been joined by four other unions. In Great Britain mergers of more than two unions are fairly common and have formed the basis of the large general unions (Elias, 1973). The merger negotiations and the resulting governing structures for mergers of more than two unions can be extremely complex. Frequently, semi-autonomous craft or industrial divisions are created along with very large governing bodies in order to represent the interests of the pre-merger members, officers and staff (Brooks and Gamm, 1976). 
These cases illustrate some important facets of union mergers which could easily be glossed over in analysis of aggregate merger data. While it would be incorrect to assume that all mergers are unique in motivation, process and structure, the characteristics described here appear worthy of more than casual attention or some brief mention in a footnote. As researchers seek to uncover the common elements in mergers, cases will be made for varied degrees of generalization. A middle ground will have to be found between overly detailed case studies and sterile aggregate data analyses. This should be dictated by a recognition of the complexity of the merger process rather than a desire to shape an analysis to fit the assumptions and format of fashionable statistical techniques.

\section{The Timing of the Merger Process}

Explanations of the causes of mergers often attempt to link the merger with some characteristics of the union or economic environment at that point in time. However, the ability to analyse merger data in this manner is severely hindered by the problems in assigning a specific date to a merger. Chaison (1980) indicated that the date recorded for a merger is most often when it was approved by the union membership or when the rnerger implementation agreement was signed. The actual negotiations for merger may have begun several years prior to the announced merger date. In some cases negotiations have been on and off for a considerable period. For example, in 1961 the United National Association of Post Office Clerks merged with the National Federation of Post Office Clerks. Earlier but unsuccessful negotiations between the two were initiated but reached impasse in 1917 and in 1933. In 1956, the Papermakers merged with the Paperworkers. The initial discussions began in 1935 and soon failed but were repeatedly reconvened over the years until successful (Graham, 1970).

Occasionally, the route to merger is not only long but may take a temporary detour. In 1961 merger negotiations began between the American Bakery and Confectionary Workers (ABC) and the Bakery and Confectionary Workers $(\mathrm{BC})$. The merger agreement received final approval in late 1969. In the course of the negotiations, the $\mathrm{BC}$ had merged into the Teamsters but separated a year later. Dewey (1971) suggested that this brief affiliation with the Teamsters may have been part of a strategy to elicit better terms in the merger with the ABC.

Chaison $(1978,1980)$ indicated that attempts to regress variables with annual merger rates, even when lagged a year or two, may confuse the date when a merger was finally approved, consumated or announced with the date when merger overtures were first made. Freeman and Brittain (1977) used a one year lag in a model relating annual merger rates to measures of strike activity, unemployment and GNP, although they indicated in a footnote that other lag structures might be more appropriate. In a study of union growth and mergers, Chaison (1981) attempted to resolve the timing problem by computing a dichotomized union growth rate for a five year period prior to the merger. Trends in merger type and number were also examined by Chaison (1980) through the use of five year periods. 
The difficulty in assigning specific dates to mergers hinders attempts to link merger frequency or form to annual measures of economic or institutional variables. A more appropriate method might be the analysis of crossclassified categorical data using broad time periods. In any case, investigators should carefully avoid confusing the date of the initial urge to merge with the date of the actual merger announcement. The time between the two may be quite long and may also vary substantially from merger to merger.

\section{The Distinction Between Amalgamations and Absorptions}

A key element in any comprehensive theory of union mergers is the distinction between amalgamations and absorptions. An amalgamation is a merger between unions while an absorption is a merger of one union into another. Chitayat $(1975,1979)$ noted the differences in negotiations and structure for the two merger forms. For example, the absorbed union's officers generally have no ability to achieve a position in the governing structure of the absorbing union, although they may be retained as consultants, division directors or other stall positions. Officers of amalgamating unions are often alloted positions in the government of the new union because of near equal size and status of the merging unions. Furthermore, absorptions generally call for only the approval of membership of the absorbed union while amalgamation requires the approval of all participating union members.

The distinction between merger types has also been made in studies of aggregate merger data. Chaison (1980b) indicated the increased frequency of absorptions and the decline in the relative proportion of amalgamations from 1900 to 1978 in the United States. Chaison (1981) uncovered differences in growth rates for absorbed, absorbing and amalgamating unions.

Future studies of mergers may have to go beyond these basic forms, and explore the varied degrees to which union governing structures are actually integrated in amalgamations or absorptions. Some absorptions are not total fusions, but may take the form of an affiliation as the "absorbed" union becomes a semi-autonomous local or division of the absorbing one. Amalgamations may entail federated structures of semi-autonomous sections or divisions (Chaison, 1980a). These structures have been widely adopted in Great Britain to reduce resistance to merger and to build large general unions (Elias, 1973; Buchanan, 1974).

While general amalgamation and absorption categories have been useful in analyses of overall merger activity, any attempts to develop microlevel theories of mergers may require a closer look at the differences within these categories. An explanation of why unions merge, or why likely merger partners have not, will require an understanding of the options that they faced in merger negotiations. The variations in amalgamations and absorptions may also be particularly important in examining the arguments that mergers result in centralized governing structures and reduced membership participation and influence (e.g. Brooks and Gamm, 1976). 


\section{The Merger as a Continuing Process}

Mergers usually have an initial transitional or stability period in which expanded or overlapping governing structures ease the way toward more complete consolidation. As Winsbury (1969) noted: "Like merged companies, merged unions take time to rationalize internally. Some unions have to digest the new acquisitions already made before they can go on to new mergers." Janus (1978) also recognized the nature of the continuing merger process: "Typically, mergers do not result in the instantaneous melding of all functions and organizational unions of the parties involved."

Coady (1976), Chitayat (1975, 1979) and Brooks and Gamm (1976) have shown that one means to reduce leadership resistance to mergers is the temporary scheme in which the incumbent leaders are given newly created offices in the merged union for a short transitional period. This results in very large governing structures to be gradually reduced in size over time. For example, an expanded structure was necessary to overcome barriers to the amalgamation of the Retail Clerks and the Amalgamated Meatcutters. The governing body of the new United Food and Commercial Workers was a President (former President of the Retail Clerks), a Secretary-Treasurer (former Secretary-Treasurer of the Meatcutters), one Executive VicePresident each from the two unions and twenty-five Vice-Presidents formerly of the Retail Clerks and twenty-three Vice-Presidents formerly of the Amalgamated Meatcutters. New officers will be elected in 1983 but the large number of Vice-President positions cannot be altered until the 1988 convention.

Some merger arrangements not only provide a transitional period with expanded or duplicating structures, but may even permit the dissolution of the mergers upon request by one of the partners. These are usually forms of absorption through affiliation. For example, the Bakery and Confectionary Workers ended its affiliation with the Teamsters after a year in 1968 and the Illinois State Employees Association with the Service Employees after eight months in 1974. (Dewey, 1971.)

Most mergers are neither complete nor instantaneous fusions of unions. Expanded governing structures may perpetuate the identities of the predecessor unions and in some cases it may take a decade or more to actually consumate the merger and streamline union organization. Studies of the impact of the mergers on union organizing, administration and governance will have to recognize these transitional procedures and bodies, particularly if attempts are made to evaluate organizational or financial conditions in the immediate post merger period.

\section{The Alliance as an Alternative to the Merger}

Union mergers are frequently seen as a way to resolve financial difficulties and to strengthen organizing or bargaining ability. However, some unions may find alternative arrangements which provide the benefits of merger without its usual degree of finality or organizational integration. 
Dewey (1971) indicated that unions may try to resolve their problems through cooperative action such as coordinated bargaining or lobbying efforts and that this may serve as a substitute for mergers. Shabecoff (1980) described the formation of an alliance of the smaller AFL-CIO affiliates to increase their influence within the federation as well as to provide services that smaller unions could not achieve individually. The smaller unions had consistently resisted merger because their officers feared that they would lose their jobs and that the union's identity and influence would be submerged in a larger organization.

Some alliances are established to smooth the way to merger. For example, the Stove, Glass and Clay Co-ordinating Committee was formed in 1970 among several AFL-CIO affiliates operating in this industry as a means to promote the mutual trust and cooperative effort needed as a prelude to amalgamations. Other forms of alliances have been carried out on a local or regional level when a more complete merger is blocked for one reason or another on the national level. Despite their inability to merge national bodies, the National Education Association and the American Federation of Teachers have formed several alliances on the state level.

Any comprehensive theory dealing with the motivation to merge or the frequency of mergers should examine organizing and bargaining alliances as either a merger substitute or prerequisite. This may be exceedingly difficult as alliances tend to be more informal and transitional than mergers, and are usually not publicly announced. However, efforts should be made to uncover alliances in industry level studies of mergers, particularly where claims are made that membership unemployment, technological change, overlapping jurisdictions have led to a strong propensity to merge.

\section{The Unsuccessful Merger Negotiations}

As institutions with complex systems of governance, strong senses of tradition, and philosophical and ideological differences, unions can often be more difficult to unite than businesses. (Business Week, 1971.) Merger negotiations are a very delicate process and many merger efforts fail, often because of disagreements over who will be the officers, the dues schedule, the size and composition of the governing bodies, and the shape of future bargaining structures (Dewey, 1971; Chitayat, 1975, 1979.) Chaison (1978) stated that successful merger negotiations might be in the minority and criticized studies which do not differentiate between the factors which cause unions to attempt to merger and those which bring about actual mergers. While it is true that the vast majority of unsuccessful merger efforts were unacknowledged by the participants and not recorded in official proceedings, there is sufficient information about some to suggest that this is a frequent and important aspect of the merger process. For example, among the major unsuccessful merger negotiations were those between:

- the Oil, Chemical and Atomic Workers and the Chemical Workers in 1968

- the Oil, Chemical and Atomic Workers and the Rubber Workers in 1975 
- the United Paperworkers and the Printing and Graphic Communications Union in 1975

- the United Paperworkers and the Chemical Workers in 1977

- the United Paperworkers and the Printing Pressmen in 1975

- the United Shoe Workers and the Boot and Shoe Workers in 1977

- the International Typographical Union and the Printing and Graphic Communications Union in 1975

- the International Longshoremens' and Warehousemens' Union and the Teamsters in 1973

- the Retail, Wholesale and Department Store Union, and the Retail Clerks and the Amalgamated Meatcutters in 1979.

In some cases, there have been series of unsuccessful merger overtures or negotiations before a successful merger was accomplished. For example, merger attempts were made between the Brewery Workers and the Amalgamated Meatcutters (1969) and the Machinists (1970) before the Brewery Workers merged into the Teamsters in 1973.

A comprehensive theory of the merger process will have to deal with the intensity and causes of the so-called "urge to merge". However, this motivation is best measured by total merger attempts rather than only those that succeed. Studies of merger frequency, whether on the industry level or in relation to general economic or institutional variables, should at the very least consider merger attempts in qualifying conclusions, and perhaps present some rough measure of the number of these attempts. It would also be enlightening to determine why merger negotiations fail, as well as how merger agreement terms are effected by past failures in these negotiations.

\section{Conclusions}

The future comprehensive and comparative theories of union mergers will integrate research from such disciplines as economics, sociology, law, organizational behavior, history and political science. Attention will focus on mergers between unions and as well as those within unions (i.e., consolidations of regional and local bodies). Studies will have to address such questions as:

1. What are the primary motivating factors causing unions to merge?

2. What political and institutional factors cause mergers and merger negotiations to succeed or fail?

3. What role can or should public policy play in altering the frequency and shaping the form of mergers?

4. What impact does a merger have on union effectiveness on national, regional and local levels? Do mergers decrease membership participation in union governance and contribute to centralized decision making within unions? 
5. How do the parties exercise bargaining power in merger negotiations? How are negotiations initiated? What methods can be used to resolve impasses in merger negotiations?

6. What are the alternative methods for integrating governing structures in mergers?

7. Do union mergers in the United States, Great Britain and Canada, among other countries, have common motivating factors and similar forms and frequency. In each country, what role in the merger process is played by the labour federations, the labour boards, the courts and union officers, staff and members?

Investigations directed at these questions could form the framework of a theory of union mergers and contribute greatly to our understanding of union structure, government and growth. This paper has suggested that a starting points in such studies is the recognition of six critical dimensions of the merger process.

\section{REFERENCES}

BROOKS, George W. and Sara GAMM, The Causes and Effects of Union Mergers, With Special Reference to Selected Cases in the 60's and 70's, Washington D.C., U.S. Department of Labor, Labor Management Services Administration, 1976.

BUCHANAN, R.T., "Merger Waves in British Unionism”, Industrial Relations Journal, vol. 5, 1974, 27-34.

CHAISON, Gary N., "Federation Expulsions and Union Mergers in the United States", Relations Industrielles - Industrial Relations, vol. 21, March 1972, 343-361.

CHAISON, Gary N., "Criticism and Comment: Union Merger Process and Industrial Environment”, Industrial Relations, vol. 7, February 1978, 119-123.

CHAISON, Gary N., "Union Mergers and International Unionism in Canada", Relations Industrielles - Industrial Relations, vol. 34, 1979, 768-777.

CHAISON, Gary N. (a), "Union Mergers, Union Fragmentation and International Unions in Canada", Seventeenth Annual Meeting of the Canadian Industrial Relations Association, Montreal, September 3, 1980.

CHAISON, Gary N. (b), "A Note on Union Merger Trends, 1900-1978”, Industrial and Labor Relations Review, vol. 34, October 1980, 114-120.

CHAISON, Gary N., "Union Mergers and Union Growth”, Industrial Relations, vol. 20, no 1, 1981, 98-107.

CHITAYAT, Gideon, “Mergers of Trade Unions”, Unpublished Ph.D. Dissertation, University of Pennsylvania, 1975.

CHITAYAT, Gideon, Trade Union Mergers and Labor Conglomerates, New York, Praeger, 1979.

COADY, Michael J., "Trade Union Mergers and their Significance in the Canadian Union Movement”, Unpublished L.L.M. Dissertation, Osgoode Hall Law School, York University, 1976. 
DEWEY, Lucretia M., “Union Merger Pace Quickens”, Monthly Labor Review, vol. 94, no. 6, June 1971, 63-70.

ELIAS, Patrick, "Trade Union Amalgamations: Patterns and Procedures", Industrial Law Journal, September 1973, 125-136.

FREEMAN, John and Jack BRITTAIN, "Union Merger Process and Industrial Environment", Industrial Relations, vol. 16, May 1977, 173-185.

FREEMAN, John and Jack BRITTAIN, "Reply to Professors Chaison and Seltzer", Industrial Relations, vol. 17, February 1978, 127-129.

GRAHAM, Harry, “Union Mergers", Relations Industrielles - Industrial Relations, vol. 25, 1970, 552-567.

JANUS, Charles J., “Union Mergers in the 1970's: A Look at the Reasons and Results", Monthly Labor Review, vol. 101, no. 10, October 1978, 13-23.

SHABECOFF, Philip, “Big Labor, Little Labor", New York Times, May 11, 1980, p. 19.

“Strenght Through Merger”, Business Week, October 2, 1971, p. 76.

WINSBURY, Rex, “The Union Urge to Merge”, Management Today, January 1969, 67-69, 106.

\section{L'efficacité des clauses d'indexations des salaires}

Les fortes poussées inflationnistes de la dernière décennie n'ont pas manqué de soulever un intérêt marqué chez plusieurs groupes sociaux, dont les travailleurs organisés, en faveur de l'indexation de leurs revenus. Quelles sont les caractéristiques principales du phénomène d'indexation des salaires au Canada? quelle en est l'étendue? quels facteurs permettent d'en expliquer l'évolution dans le temps? quel est et comment mesurer le degré d'efficacité de telles clauses dans les conventions collectives? quels en sont les effets sur les structures de salaires, tant au niveau local que national, sur les coûts de production et sur l'inflation? Voilà parmi d'autres un certain nombre de questions qui préoccupent tant l'analyste que l'acteur immédiat du système de relations industrielles.

Parmi les quelques études récentes sur le sujet au Canada, deux ont suscité des commentaires critiques particulièrement au niveau du concept d'efficacité des clauses d'indexation et de sa mesure. La première réalisée par Jean-Michel Cousineau et Robert Lacroixl de l'Université de Montréal utilise des données inédites de Travail Canada sur l'ensemble des conventions de 200 employés et plus au Canada, à l'exclusion du secteur de la construction, et couvre la période 1970 à 1977. Dans la seconde, Sharon Michaud et Jean-Charles Roy ${ }^{2}$ de Travail Canada appuient leurs observations sur des données provenant des conventions collectives de 500 employés et plus au Canada, à l'exclusion du secteur de la construction, signées entre janvier 1978 et décembre 1980.

1 COUSINEAU, Jean-Michel et Robert LACROIX, L'indexation des salaires, École de relations industrielles, Université de Montréal, série Monographie no 10, 1981, 119 pages.

2 MICHAUD, Sharon et Jean-Charles ROY, Grands accords salariaux comportant une clause d'indemnité de vie chère - Estimations des augmentations salariales correspondant à des taux d'inflation donnés 1978-1980, Document de travail, Travail Canada, Direction de l'analyse économique, Ottawa, mai 1981, 58 pages. 